\title{
Synthesis of 5,6-Dihydro[1,10]phenanthroline Derivatives and Their Properties as Hole-Blocking Layer Materials for Phosphorescent Organic Light-Emitting Diodes
}

\author{
Hyo Won Lee, Jung-Gi An, Hee-Kyoon Yoon, Hyosook Jang, ${ }^{\dagger}$ Nam Gwang Kim, ${ }^{\dagger}$ and Youngkyu Do ${ }^{\dagger, *}$ \\ Department of Chemistry, Chungbuk National University, Cheongju 361-763, Korea. "E-mail: hwnlee@cbucc.chungbuk.ac.kr \\ 'Department of Chemistry, School of Molecular Science-BK21 and Center for Molecular Design and Synthesis, \\ KAIST, Daejeon 305-701, Korea. "E-mail: ykdo@kaist.ac.kr \\ Received July 11, 2005
}

\begin{abstract}
To develop new hole-blocking materials for phosphorescent organic light-emitting diodes (PhOLEDs), 5,6dihydro-2,9-diisopropyl-4,7-diphenyl[1,10]phenanthroline (1) and 5,6-dihydro-2,9-diisopropyl-4-(4-methoxyphenyl)-7-phenyl[1,10]phenanthroline (2) were synthesized. While the absorption spectrum of $\mathbf{1}$ is very similar to that of $\mathbf{2}$, the photoluminescence spectrum of $\mathbf{1}$ has the feature of the narrower and blue-shifted blueviolet emission at the peak of $356 \mathrm{~nm}$ compared to that of $\mathbf{2}$. The HOMO and LUMO energy levels of $\mathbf{1}$ and $\mathbf{2}$ were estimated from the measurement of cyclic voltammetry, and $\mathbf{1}$ has the appropriate levels for a holeblocking layer (HBL). The use of $\mathbf{1}$ as a HBL in a green PhOLED led to good efficiency of $23.6 \mathrm{~cd} / \mathrm{A}$ at 4.4 $\mathrm{mA} / \mathrm{cm}^{2}$.
\end{abstract}

Key Words : BCP derivatives, 5,6-Dihydro-2,9-diisopropyl-4,7-diaryl[1,10]phenanthroline, Hole-blocking materials, Phosphorescent organic light-emitting diode

\section{Introduction}

In recent years, the application of organic light-emitting diode (OLED) has been increasing due to the advantages of self-emission, fast response time, high brightness, and so on. ${ }^{1}$ Hence, in particular, the studies on OLED materials and devices have been actively directed toward achieving higher performance, leading to, among others, the use of the phosphorescent materials as emitting materials for OLED (PhOLED). ${ }^{2}$ The PhOLED utilizes both singlet and triplet excitons. $^{3}$ The longer lifetime and the diffusion length of triplet excitons compared to those of singlet excitons ${ }^{4}$ make the PhOLED generally require either the use of an additional hole-blocking layer (HBL) between the emitting layer (EML) and the electron-transporting layer (ETL) or the employment of the electron-transporting layer with holeblocking ability (HBETL) instead of ETL in the general OLED structure of anode/hole-transporting layer (HTL)/ EML/ETL/cathode. The purpose of the use of HBL or HBETL is to increase the electroluminescence (EL) efficiency by confining the recombination of injected holes and electrons and the relaxation of created excitons within the EML. ${ }^{5,6}$ To meet such roles, the hole-blocking materials should have HOMO and LUMO energy levels suitable to block hole transport from the EML to the ETL and to pass electrons from the ETL to the EML in addition to the good thermal and electrochemical stability. ${ }^{7}$ Currently, the examples of the hole-blocking materials are very limited and 2,9-dimethyl-4,7-diphenyl-1,10-phenanthroline, known also as bathocuproine (BCP), ${ }^{\text {a }}$ and bis(2-methyl-8-quinolinolato)mono(4-phenylphenolato)aluminum $(\mathrm{BAlq})^{8}$ have been used as the typical materials for the HBL and HBETL of PhOLED, respectively. However, they show several problems such as the low thermal stability and the high driving voltage. As a part of our efforts in synthesizing new hole-blocking materials, the derivatization of BCP has been attempted. Reported herein are the synthesis of 5,6-dihydro2,9-diisopropyl-4,7-diphenyl[1,10]phenanthroline (1) and 5,6-dihydro-2,9-diisopropyl-4-(4-methoxyphenyl)-7-phenyl$[1,10]$ phenanthroline (2), whose structures are shown in Scheme 1, and the accounts of their properties as holeblocking layer materials in a green-emitting phosphorescent OLED.

\section{Experimental Section}

General Comments. Unless otherwise indicated in a specific experiment, all of the chemicals used were reagent grade and no additional purification has been done. Tetrahydrofuran (THF) was distilled from sodium benzophenone ketyl immediately prior to use. Dichloromethane $\left(\mathrm{CH}_{2} \mathrm{Cl}_{2}\right)$ was distilled from calcium hydride. Thin layer chromatography (TLC) was performed on E. Merk silica gel plates (60F-254) with $0.25 \mathrm{~mm}$ thickness. Colorization of spots on TLC plates was performed by heating with acidic $p$ anisaldehyde solution or $7 \%$ ethanolic phosphomolybdic acid. Flash column chromatography was performed on E. Merk silica gel (F60, 230-400 mesh).

General Synthesis of Methyl-1-(4-substituted phenyl)pent-en-3-ones. To a solution of benzaldehyde compound (50 mmol) and 3-methylbutan-2-one (13.4 mL, $125 \mathrm{mmol})$ in ethanol $(15 \mathrm{~mL})$ was added $10 \%$ aqueous $\mathrm{NaOH}(1.25$ $\mathrm{mL})$ dropwise slowly under the nitrogen atmosphere keeping the inner temperature of the reaction mixture below $30{ }^{\circ} \mathrm{C}$. After stirring at room temperatue for $6 \mathrm{~h}$, reaction mixture was acidified to $\mathrm{pH} 2$ with dilute $\mathrm{HCl}$ solution. The reaction mixture was extracted with benzene $(3 \times 30 \mathrm{~mL})$ and the combined extract was dried over anhydrous $\mathrm{MgSO}_{4}$, 
filtered, and concentrated in vacuo to obtain the crude residue. The crude product was eluted with a mixture of Hexane : EtOAc $=10: 1$ on a silica gel column to obtain the product.

Methyl-1-phenylpent-1-en-3-ones (5). (7.8 g, 90\%). ${ }^{1} \mathrm{H}$ NMR (300 MHz, $\left.\mathrm{CDCl}_{3}, \delta\right): 7.60(\mathrm{~d}, J=16.1 \mathrm{~Hz}, 1 \mathrm{H}$, $\mathrm{ArCH}=\mathrm{CH}), 7.55$ (m, 2H, $\mathrm{ArH}), 7.55$ (m, 3H, $\mathrm{ArH}), 6.81(\mathrm{~d}$, $J=16.0 \mathrm{~Hz}, 1 \mathrm{H}, \mathrm{ArCH}=\mathrm{CH}), 2.92\left(\mathrm{~m}, 1 \mathrm{H}, \mathrm{CH}\left(\mathrm{CH}_{3}\right)_{2}\right), 1.17$ $\left(\mathrm{d}, J=6.9 \mathrm{~Hz}, 6 \mathrm{H}, \mathrm{CH}\left(\mathrm{CH}_{3}\right)_{2}\right)$; IR $\left(v_{\max }, \mathrm{KBr}\right): 2967,1687$, $1663,1612,1450,1205,1055 \mathrm{~cm}^{-1}$.

4-Methyl-1-(4-methoxyphenyl)pent-1-en-3-one (6). (8.3 g, 81\%). ${ }^{1} \mathrm{H}$ NMR $\left(300 \mathrm{MHz}, \mathrm{CDCl}_{3}, \delta\right): 7.54$ (d, $J=16.0$ $\mathrm{Hz}, 1 \mathrm{H}, \mathrm{ArCH}=\mathrm{CH}), 7.48(\mathrm{~d}, J=8.8 \mathrm{~Hz}, 2 \mathrm{H}, \mathrm{Ar} H), 6.87$ (d, $J=8.8 \mathrm{~Hz}, 2 \mathrm{H}, \mathrm{ArH}), 6.67(\mathrm{~d}, J=15.9 \mathrm{~Hz}, 1 \mathrm{H}, \mathrm{ArCH}=\mathrm{CH})$, $3.79\left(\mathrm{~s}, 3 \mathrm{H}, \mathrm{OCH}_{3}\right), 2.91-2.86\left(\mathrm{~m}, 1 \mathrm{H}, \mathrm{CH}\left(\mathrm{CH}_{3}\right)_{2}\right), 1.10(\mathrm{~d}, J$ $\left.=6.9 \mathrm{~Hz}, 6 \mathrm{H}, \mathrm{CH}\left(\mathrm{CH}_{3}\right)_{2}\right)$; IR ( $v_{\max }$, neat): 2968, 1684, 1658, $1598,1464,1254,1174 \mathrm{~cm}^{-1}$.

1-Cyclohexenyloxytrimethylsilane (7). To a solution of diisopropylamine $(6.10 \mathrm{~g}, 61.1 \mathrm{mmol})$ in THF $(30 \mathrm{~mL})$ at 0 ${ }^{\circ} \mathrm{C}$ under the nitrogen atomosphere was added $n$-BuLi $(2.5$ $\mathrm{M}$ in hexane $24 \mathrm{~mL}$ ) dropwise via syringe and the reaction mixture was stirred for $30 \mathrm{~min}$. Then the reaction mixture of LDA was cooled to $-78{ }^{\circ} \mathrm{C}$ and cyclohexanone (5.00 g, 50.9 $\mathrm{mmol})$ was added. After stirring for $30 \mathrm{~min}$, TMSCl $(60$ mmol) was added. The resulting reaction mixture was concentrated in vacuo. The residue was dissolved in hexane, filtered through a pad of Celite 545, concentrated under the reduced pressure to obtain crude product as a pale yellow liquid $(9.9 \mathrm{~g}, 95 \%)$.

2-[4-Methyl-3-oxo-1-(4-phenyl)pentyl]cyclohexanone (8). To a solution of ketone $5(2.87 \mathrm{mmol})$ in $\mathrm{CH}_{2} \mathrm{Cl}_{2}(5 \mathrm{~mL})$ in a two-necked round bottomed flask equipped with an additional funnel at $-40{ }^{\circ} \mathrm{C}$ under nitrogen atomosphere was added $\mathrm{TiCl}_{4}(315 \mu \mathrm{L}, 2.87 \mathrm{mmol})$ dropwise. After stirring for $5 \mathrm{~min}$ a solution of 1-cyclohexenyloxytrimethylsilane 7 (3.45 mmol) in $\mathrm{CH}_{2} \mathrm{Cl}_{2}(2 \mathrm{~mL})$ was added to the reaction solution for $30 \mathrm{~min}$. After additional stirring for $30 \mathrm{~min}$, the temperature of the reaction mixture was raised to room temperature and water was added to quench the reaction. The reaction mixture was extracted with ether $(3 \times 10 \mathrm{~mL})$. The combined extracts were dried over anhydrous $\mathrm{Na}_{2} \mathrm{SO}_{4}$, filtered, concentrated in vacuo. The residue was chromatographed on a short column of silica gel eluting with hexane : ethyl acetate $=15: 1$ to obtain crude 1,5-diketone 8, which was used for the next step without further purification (594 $\mathrm{mg}, 76 \%$ ).

2-Isopropyl-4-(4-phenyl)-5,6,7,8-tetrahydroquinoline (9). To a solution of 1,5-diketone $8(0.73 \mathrm{mmol})$ in acetic acid $(5 \mathrm{~mL})$ was added ammonium acetate $(168 \mathrm{mg}, 2.18$ mmol). The resulting solution was refluxed for $2 \mathrm{~h}$. Then the reaction mixture was cooled to $0{ }^{\circ} \mathrm{C}$ and neutralized with $20 \% \mathrm{NaOH}$ solution. The reaction mixture was extracted with $\mathrm{CH}_{2} \mathrm{Cl}_{2}(3 \times 10 \mathrm{~mL})$ and combined extracts were dried over anhydrous $\mathrm{Na}_{2} \mathrm{SO}_{4}$, filtered, and concentrated under reduced pressure. The residue was purified by column chromatography on silica gel (Hexane : Ethyl acetate $=7: 1$ ) to furnish tetrahydroquinoline product 9 as a solid (128 mg,
70\%). mp: 53.5-55 ${ }^{\circ} \mathrm{C} ;{ }^{1} \mathrm{H}$ NMR (300 MHz, $\mathrm{CDCl}_{3}, \delta$ ): 7.46$7.38(\mathrm{~m}, 3 \mathrm{H}, \mathrm{ArH}), 7.31-7.28(\mathrm{~m}, 2 \mathrm{H}, \mathrm{ArH}), 6.87(\mathrm{~s}, 1 \mathrm{H}$, $\mathrm{ArH}), 3.09-3.00\left(\mathrm{~m}, 1 \mathrm{H}, \mathrm{CH}\left(\mathrm{CH}_{3}\right)_{2}\right), 2.98$ (t, $J=6.5 \mathrm{~Hz}, 2 \mathrm{H}$, $\left.\mathrm{ArCH}_{2} \mathrm{CH}_{2}\right), 2.59$ (t, $\left.J=6.3 \mathrm{~Hz}, 2 \mathrm{H}, \mathrm{ArCH}_{2} \mathrm{CH}_{2}\right), 1.94-1.86$ (m, 2H, $\mathrm{ArCH}_{2} \mathrm{CH}_{2}$ ), 1.75-1.67 (m, 2H, $\left.\mathrm{ArCH}_{2} \mathrm{CH}_{2}\right), 1.30$ (d, $\left.J=6.9 \mathrm{~Hz}, 6 \mathrm{H}, \mathrm{CH}\left(\mathrm{CH}_{3}\right)_{2}\right) ;{ }^{13} \mathrm{C} \mathrm{NMR}\left(125 \mathrm{MHz} \mathrm{CDCl}_{3}\right.$, d): $163.8,156.3,149.8,139.8,128.3,128.0,127.3,126.8$, $118.0,36.0,33.0,27.0,23.0,22.9,22.7$; IR ( $\left.v_{\max }, \mathrm{KBr}\right)$ : $2963,1585,1545,1445,1375,1086 \mathrm{~cm}^{-1}$.

8-Benzylidenyl-2-isopropyl-4-phenyl-5,6,7,8-tetrahydroquinoline (10). A solution of $9(5.0 \mathrm{~g}, 19.9 \mathrm{mmol})$ and benzaldehyde $(2.62 \mathrm{~mL}, 25.6 \mathrm{mmol})$ in acetic anhydride $(20$ $\mathrm{mL}$ ) was refluxed at $170{ }^{\circ} \mathrm{C}$ for $14 \mathrm{~h}$ under nitrogen atmosphere. After cooling the reaction mixture was neutralized with aqueous $10 \% \mathrm{NaOH}$ solution. The reaction mixture was extracted with $\mathrm{CH}_{2} \mathrm{Cl}_{2}(3 \times 30 \mathrm{~mL})$. The combined extracts were dried over anhydrous $\mathrm{MgSO}_{4}$, filtered and concentrated in vacuo. The residue was separated on a silica gel column (hexane : ethyl acetate $=15$ : 1) to obtain product as a yellow syrup 10. (3.9 g, 58\%). ${ }^{1} \mathrm{H}$ NMR (300 MHz, $\left.\mathrm{CDCl}_{3}, \delta\right): 8.08(\mathrm{~s}, 1 \mathrm{H}, \mathrm{ArCH}=\mathrm{CH}), 7.39-$ $7.17(\mathrm{~m}, 10 \mathrm{H}, \operatorname{ArH}), 6.87(\mathrm{~s}, 1 \mathrm{H}, \mathrm{ArH}), 3.05-2.98(\mathrm{~m}, 1 \mathrm{H}$, $\left.\mathrm{CH}\left(\mathrm{CH}_{3}\right)_{2}\right), 2.85-2.81\left(\mathrm{~m}, 2 \mathrm{H}, \mathrm{ArCH}_{2} \mathrm{CH}_{2}\right), 2.62(\mathrm{t}, J=6.0$ $\left.\mathrm{Hz}, 2 \mathrm{H}, \mathrm{CCH}_{2} \mathrm{CH}_{2}\right), 1.70-1.62\left(\mathrm{~m}, 2 \mathrm{H}, \mathrm{ArCH}_{2} \mathrm{CH}_{2}\right), 1.29$ (d, $\left.J=6.9 \mathrm{~Hz}, 6 \mathrm{H}, \mathrm{CH}\left(\mathrm{CH}_{3}\right)_{2}\right) ;{ }^{13} \mathrm{C} \mathrm{NMR}\left(125 \mathrm{MHZ}, \mathrm{CDCl}_{3}\right.$, $\delta): 163.8,151.7,149.8,139.8,138.2,136.2,129.6,128.6$, $128.1,127.9,127.5,127.4,127.1,126.4,119.9,36.1,28.0$, 27.7, 23.0, 22.6; IR ( $\left.v_{\max }, \mathrm{KBr}\right): 3054,2960,1581,1540$, $1494,1389,1240 \mathrm{~cm}^{-1}$.

2-Isopropyl-4-phenyl-6,7-dihydro-5H-quinolin-8-one (11). To a solution of compound $10(600 \mathrm{mg}, 1.77 \mathrm{mmol})$ in a mixture of $\mathrm{CH}_{2} \mathrm{Cl}_{2}$ : methanol $=1: 1(20 \mathrm{~mL})$ at $-78{ }^{\circ} \mathrm{C}$ was passed ozone until the solution turned to blue. Then, the reaction flask was flushed with nitrogen gas and dimethyl sulfide (439 mg, $7.07 \mathrm{~mol}$ ) was added to the reaction mixture. After stirring for $1 \mathrm{~h}$ at room temperature, the reaction mixture was extracted with $\mathrm{CH}_{2} \mathrm{Cl}_{2}(3 \times 10 \mathrm{~mL})$. The combined extracts were dried over anhydrous $\mathrm{MgSO}_{4}$, filtered, and concentrated in vacuo. The residue was separated on a column of silica gel eluting with hexane : ethyl acetate $=4: 1$ to obtain the product as a white solid 11 (421 mg, 90\%). mp: 96.6-97.5 ${ }^{\circ} \mathrm{C}$; ${ }^{1} \mathrm{H}$ NMR (500 MHz, $\left.\mathrm{CDCl}_{3}, \delta\right): 7.50-7.43(\mathrm{~m}, 3 \mathrm{H}, \mathrm{ArH}), 7.33(\mathrm{~d}, J=7.1,2 \mathrm{H}$, $\mathrm{ArH}), 7.26$ (s, 1H, $\mathrm{ArH}), 3.32-3.26\left(\mathrm{~m}, 1 \mathrm{H}, \mathrm{CH}\left(\mathrm{CH}_{3}\right)_{2}\right), 2.88$ $\left(\mathrm{t}, J=5.9 \mathrm{~Hz}, 2 \mathrm{H}, \mathrm{COCH}_{2} \mathrm{CH}_{2}\right), 2.80(\mathrm{t}, J=6.5 \mathrm{~Hz}, 2 \mathrm{H}$, $\mathrm{ArCH}_{2} \mathrm{CH}_{2}$ ), 2.09-2.05 (m, 2H, $\left.\mathrm{ArCH}_{2} \mathrm{CH}_{2}\right), 1.33$ (d, $J=6.9$ $\left.\mathrm{Hz}, 6 \mathrm{H}, \mathrm{CH}\left(\mathrm{CH}_{3}\right)_{2}\right) ;{ }^{13} \mathrm{C} \mathrm{NMR}\left(125 \mathrm{MHz}, \mathrm{CDCl}_{3}, \delta\right): 197.3$, 166.6, 151.3, 148.0, 138.6, 136.5, 128.9, 128.7, 124.5, 40.0, 36.7, 27.6, 23.1, 23.0; IR ( $\left.v_{\max }, \mathrm{KBr}\right): 3061,2965,1701$, $1586,1495,1302,1161,1036 \mathrm{~cm}^{-1}$.

2,9-Diisopropyl-4-phenyl-7-(4-substitutedphenyl)-5,6dihydro[1,10]phenanthroline. To a stirred slurry of sodium hydride $(21.6 \mathrm{mg}, 0.79 \mathrm{mmol}$ in THF $(5 \mathrm{~mL})$ at 0 was added solution of $11(200 \mathrm{mg}, 0.75 \mathrm{mmol})$ in THF $(2 \mathrm{~mL})$ under nitrogen atmosphere. Then ketone 5 or $6(0.79 \mathrm{mmol})$ in THF $(2 \mathrm{~mL})$ was added dropwise to the reaction mixture and stirring was continued for $10 \mathrm{~h}$ at room temperature. 
Reaction was quenched by adding saturated aqueous $\mathrm{NH}_{4} \mathrm{Cl}$ solution $(5 \mathrm{~mL})$ to the reaction mixture. The reaction mixture was extracted with ethyl acetate $(3 \times 10 \mathrm{~mL})$. The combined extracts were dried over anhydrous $\mathrm{MgSO}_{4}$, filtered and concentrated in vacuo. The residue was filtered through short silica gel column (hexane : ethyl acetate $=7$ : 1 ) to obtain crude 1,5-diketone product, which was used for the next step without further purificaition. $12(228 \mathrm{mg}$, $83 \%), 13$ (278 mg, 75\%). To a stirred solution of diketone 12 or $13(0.4 \mathrm{mmol})$ in acetic acid $(10 \mathrm{~mL})$ was added ammonium acetate $(100 \mathrm{mg}, 1.3 \mathrm{mmol})$. The reaction mixture was refluxed for $3 \mathrm{~h}$. After cooling the reaction mixture was neutralized with aqueous $20 \% \mathrm{NaOH}$ solution. The reaction mixture was extracted with ethyl acetate $(3 \times 5$ $\mathrm{mL})$. The combined extracts were dried over anhydrous $\mathrm{Na}_{2} \mathrm{SO}_{4}$, filtered, and concentrated under reduced pressure. The residue was separated on a column of silica gel eluting with hexane : ethyl acetate $=4: 1$ to get 5,6-dihydro$[1,10]$ phenanthroline as a white solid.

2,9-Diisopropyl-4,7-diphenyl-5,6-dihydro-[1,10]phenanthroline (1). (124 mg, 74\%); mp: 182-184 ${ }^{\circ} \mathrm{C}$; ${ }^{1} \mathrm{H} \mathrm{NMR}$ (300 MHz, $\mathrm{CDCl}_{3}, \delta$ ): 7.48-7.31 (m, 5H, $\left.\mathrm{ArH}\right), 7.14(\mathrm{~s}, 1 \mathrm{H}$, $\mathrm{Ar} H), 3.41-3.32\left(\mathrm{~m}, 2 \mathrm{H}, \mathrm{CH}\left(\mathrm{CH}_{3}\right)_{2}\right), 2.75(\mathrm{~s}, 2 \mathrm{H}$, $\left.\mathrm{ArCH}_{2} \mathrm{CH}_{2}\right), 1.40\left(\mathrm{~d}, J=7.1 \mathrm{~Hz}, 6 \mathrm{H}, \mathrm{CH}\left(\mathrm{CH}_{3}\right)_{2}\right) ;{ }^{13} \mathrm{C} \mathrm{NMR}$ $\left(75 \mathrm{MHz}, \mathrm{CDCl}_{3}, \delta\right.$ ): 164.8, 150.9, 147.4, 138.2, 127.9, 127.7, 127.2, 126.8, 119.5, 35.3, 23.9, 21.9; IR ( $\left.v_{\max }, \mathrm{KBr}\right)$ : $3051,2955,1579,1548,1495,1225,1058 \mathrm{~cm}^{-1}$. HRMS $(\mathrm{m} / \mathrm{z})$ : Calcd for $\mathrm{C}_{30} \mathrm{H}_{30} \mathrm{~N}_{2}, 418.2409$; found, 418.2408.

2,9-Diisopropyl-4-phenyl-7-(4-methoxyphenyl)-5,6-dihydro-[1,10]phenanthrolin (2). (104 mg, 54\%); mp: 67-71 ${ }^{\circ} \mathrm{C}$; ${ }^{1} \mathrm{H}$ NMR (500 MHz, $\mathrm{CDCl}_{3}, \delta$ ): 7.46-7.34 (m, 5H, $\mathrm{ArH}$ ), 7.28 (d, $J=8.7,2 \mathrm{H}, \mathrm{ArH}), 7.15$ (s, 1H, ArH), 7.14 (s, 1H, $\mathrm{ArH}), 6.98(\mathrm{~d}, J=8.7,2 \mathrm{H}, \mathrm{ArH}), 3.85$ (s, 3H, $\left.\mathrm{OCH}_{3}\right), 3.41-$ 3.35 (m, 2H, $\left.\mathrm{CH}\left(\mathrm{CH}_{3}\right)_{2}\right), 2.80-2.75$ (m, 4H, $\left.\mathrm{ArCH} \mathrm{CH}_{2} \mathrm{Ar}\right)$, $1.42\left(\mathrm{~d}, J=6.9 \mathrm{~Hz}, 12 \mathrm{H}, \mathrm{CH}\left(\mathrm{CH}_{3}\right)_{2}\right) ;{ }^{13} \mathrm{C} \mathrm{NMR}(75 \mathrm{MHz}$, $\left.\mathrm{CDCl}_{3}, \delta\right): 166.3,166.2,159.8,152.5,152.4,148.9,148.6$, $139.7,131.9,130.5,129.5,129.4,129.2,128.8,128.3$, 121.1, 121.0, 114.2, 55.7, 36.8, 25.5, 25.4, 23.4; IR ( $v_{\max }$, $\mathrm{KBr}): 2958,1597,1512,1248,1177 \mathrm{~cm}^{-1}$. HRMS $(\mathrm{m} / \mathrm{z})$ : Calcd for $\mathrm{C}_{31} \mathrm{H}_{32} \mathrm{~N}_{2} \mathrm{O}$, 448.2515; found, 448.2516.

Instrumentation. Melting points were determined on either Electrothermal AZ9003 NK3 or IA 9100 apparatus in capillary tubes and are uncorrected. Infrared (IR) spectra were recorded on a JASCO FT-IR 680 plus spectrometer. NMR spectra were recorded on either Bruker DPX-300 or AMX-500 spectrometer. The ${ }^{1} \mathrm{H}$ NMR spectra were measured in $\mathrm{CDCl}_{3}$ solution, unless otherwise stated, relative to tetramethylsilane as an internal standard $(\delta=0.00 \mathrm{ppm})$. For ${ }^{13} \mathrm{C}$ spectra, the middle peak of $\mathrm{CDCl}_{3}$ triplet was used as reference peak $(\delta=77.0 \mathrm{ppm})$. Elemental analyses were performed on an EA1110-FISONS (CE Instruments) by the Chemical Analysis Laboratory at KAIST. HRMS data were obtained by the Environmental Analysis Laboratory at KAIST on a VG Autospec Ultma. Thermogravimetric analyses (TGA) were carried out under a nitrogen atmosphere at a heating rate of $10{ }^{\circ} \mathrm{C} / \mathrm{min}$ with Dupont 9900 Analyzer. UV/Vis spectra were obtained on Jasco V-530 spectro- photometer. PL spectra were recorded on a Spex Fluorog-3 luminescence spectrometer. Cyclic voltammetry was performed on an AUTOLAP/PGSTAT12 with a three-electrode cell in an acetonitrile solution of $\mathrm{Bu}_{4} \mathrm{NBF}_{4}(0.10 \mathrm{M})$ at a scan rate of $50 \mathrm{mV} / \mathrm{s}$. All measurements were carried out at room temperature under ambient atmosphere.

\section{Results and Discussion}

Synthesis. The overall synthetic routes are outlined in Scheme 1. In order to prepare a Michael acceptor for 1,5diketone $(\mathbf{8})$, benzaldehyde 3 and $p$-anisaldehyde 4 were condensed with 3-methylbutan-2-one under basic condition to obtain $\alpha, \beta$-unsaturated ketones 5 and $\mathbf{6}$, respectively. The following Mukaiyama-Michael reaction of 5 with TMS ether 7 of cylohexenol furnished the desired 1,5-diketone 8, which upon treatment in a refluxing mixture of $\mathrm{NH}_{4} \mathrm{OAc} /$ HOAc and subsequent neutralization with $\mathrm{NaOH}$ afforded pyridine compound $\mathbf{9}$. The required ketone $\mathbf{1 1}$ was prepared in two steps according to Thummel's method. ${ }^{9}$ The treatment of compound 9 with benzaldehyde in acetic anhydride provided $\alpha$-benzylidene derivative 10. And the subsequent ozonolysis provided diketone 11. The next step along the sequence was the introduction of 1,5-diketone with an aromatic unit from compound $\mathbf{1 1}$ for the transformation to the second pyridine unit. Thus Michael addition reaction of 5 and 6 with 11 under basic condition gave corresponding 1,5-diketone $\mathbf{1 2}$ and $\mathbf{1 3}$, respectively. Subsequent reaction of 12 and 13 with $\mathrm{NH}_{4} \mathrm{OAc}$ in acetic anhydride finally yielded dihydro compound $\mathbf{1}$ and $\mathbf{2}$.

Properties. The BCP derivatives $\mathbf{1}$ and $\mathbf{2}$ are air-stable in the solid and solution states. Melting points and $5 \mathrm{wt} \%$ decomposition temperatures $\left(\mathrm{T}_{\mathrm{d} 5}\right)$ were investigated to estimate the thermal stability. The $T_{\mathrm{d} 5}$ values of $\mathbf{1}$ and $\mathbf{2}$ are 250 and $220{ }^{\circ} \mathrm{C}$, respectively and rather low for the use in OLEDs. Contrary to the similar $\mathrm{T}_{\mathrm{d} 5}$ values, the melting points of $\mathbf{1}$ and $\mathbf{2}$ are markedly different as 183 and $70{ }^{\circ} \mathrm{C}$, respectively. It is considered that the introduction of methoxy unit causes the decrease of melting point in $\mathbf{2}$.

The absorption and emission spectra of $\mathbf{1}$ and $\mathbf{2}$ in $\mathrm{CHCl}_{3}$ solution are illustrated in Figure 1 and their summary is listed in Table 1. While the UV-Vis spectra of $\mathbf{1}$ and $\mathbf{2}$ are almost alike, the features of photoluminescence (PL) spectra are clearly different in the position of the maximum emission wavelength and in the full-width at the halfmaximum (FWHM). The compounds $\mathbf{1}$ and $\mathbf{2}$ emit blueviolet and sky-blue fluorescence, respectively, with the relatively low PL efficiency ${ }^{10}$ around 0.007-0.014.

Cyclic voltammetry was employed to estimate the HOMO and LUMO energy levels from redox behaviors. All measurements were calibrated using the ferrocence/ferrocenium redox system as a standard. ${ }^{11}$ The electrochemical data are summarized in Table 2. Both compounds undergo reversible reduction and irreversible oxidation processes. It is expected that the reversible cathodic reduction raises the probability of stable anion radicals and enables steady injection and transport of electrons in OLEDs. However, 2 seems 
<smiles>[R]c1ccc(/C=C/C(=O)C(C)C)cc1</smiles><smiles>COc1ccccc1</smiles>

7<smiles>CC(C)c1cc(-c2ccccc2)c2c(n1)C(=O)CCC2</smiles><smiles>CC(C)C(=O)CC(c1ccccc1)C1CCCCC1=O</smiles><smiles>C1CCCCC1</smiles><smiles>CC(C)c1cc(-c2ccccc2)c2c(n1)CCCC2</smiles>

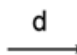<smiles>CC(C)c1cc(-c2ccccc2)c2c(n1)/C(=C/c1ccccc1)CCC2</smiles><smiles>CC(C)C(C)(C)C</smiles><smiles>[R]c1ccc(C(CC(=O)C(C)C)C2CCc3c(-c4ccccc4)cc(C(C)C)nc3C2=O)cc1</smiles>
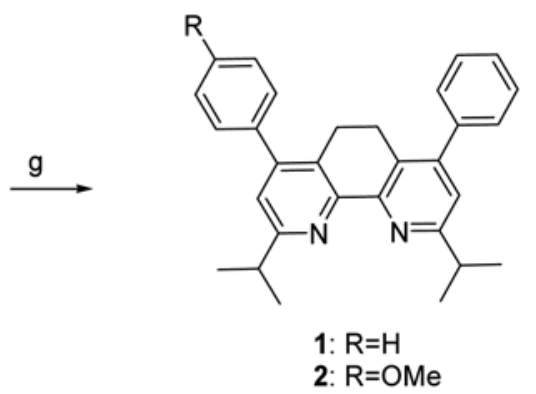

Scheme 1. Reagents: a. 3-methylbutan-2-one, $10 \% \mathrm{NaOH}, \mathrm{EtOH}, \mathrm{R}=\mathrm{H}, 90 \%$, $\mathrm{R}=\mathrm{OMe}, 81 \%$; b. 7, $\mathrm{TiCl}_{4}, \mathrm{CH}_{2} \mathrm{Cl}_{2},-40{ }^{\circ} \mathrm{C}, 76 \%$; c. $\mathrm{NH}_{4} \mathrm{OAc}$, reflux, $70 \%$; d. benzaldehyde, $\mathrm{Ac}_{2} \mathrm{O}, 170{ }^{\circ} \mathrm{C}, 58 \%$; e. Oe, $-78{ }^{\circ} \mathrm{C}$; $\mathrm{Me}_{2} \mathrm{~S}, 90 \%$; f. NaH, 5 or 6 , THF, $0{ }^{\circ} \mathrm{C}-\mathrm{rt}, \mathrm{R}=\mathrm{H}, 83 \%, \mathrm{R}=\mathrm{OMe}, 75 \%$; g. $\mathrm{NH} 4 \mathrm{OAc}, \mathrm{AcOH}$, reflux, $\mathrm{R}=\mathrm{H}, 74 \%, \mathrm{R}=\mathrm{OMe}, 54 \%$.

electrochemically unstable because another peak is created and emitting color varies from sky-blue to greenish-blue as the scan number increases. In the anodic scan, each onset of oxidation ( $p$-doping) of $\mathbf{1}$ and $\mathbf{2}$ appeared at 2.32 and $1.98 \mathrm{~V}$ that correspond to HOMO energy levels of -6.72 and -6.38

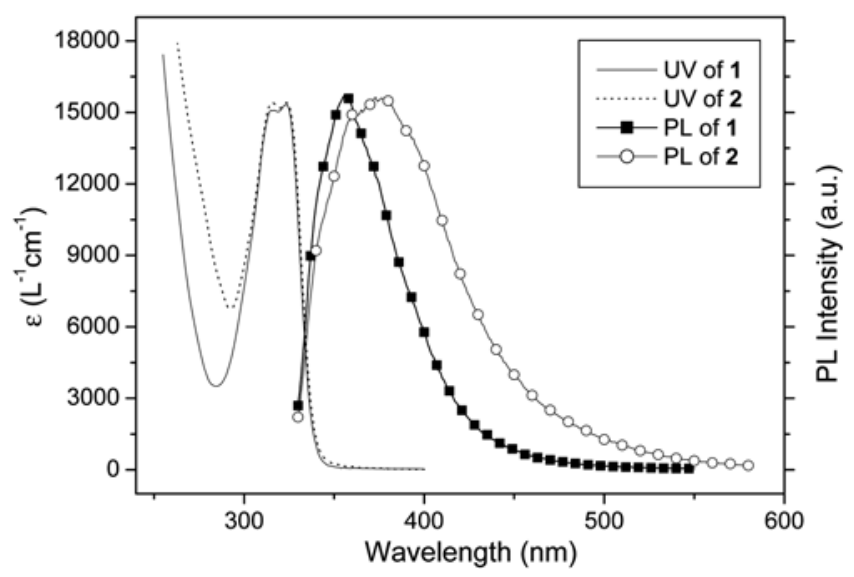

Figure 1. UV-Vis and PL spectra of $\mathbf{1}$ and $\mathbf{2}$ in $\mathrm{CHCl}_{3}$ solution.
$\mathrm{eV}$, respectively. The cathodic scan gave each onset reduction ( $n$-doping) potential of -0.99 and $-0.87 \mathrm{~V}$ for $\mathbf{1}$ and $\mathbf{2}$ and the LUMO energy levels were calculated at -3.41 and $-3.53 \mathrm{eV}$, respectively. ${ }^{12}$ Especially, the HOMO level of $\mathbf{1}$ is much lower than that of $\mathbf{2}$ and the energy levels of $\mathbf{1}$ are similar to those of BCP, a typical hole-blocking material. ${ }^{5 a}$

The methoxy-containing compound $\mathbf{2}$ shows lower thermal and electrochemical stability, narrower bandgap and higher HOMO level as compared with $\mathbf{1}$. Therefore, only 1based green PhOLED was fabricated with the structure of ITO / aromatic amine $(650 \AA) / \mathrm{NPD}(100 \AA) / \mathrm{CBP}+8 \mathrm{wt} \%$ $\operatorname{Ir}(\text { ppy })_{3}(300 \AA) / 1(50 \AA) / \operatorname{Alq}_{3}(350 \AA) / \mathrm{Al}(1000 \AA)$ to evaluate hole-blocking layer property of $\mathbf{1}$ (Figure 2). The EL spectrum of pure $\operatorname{Ir}(\mathrm{ppy})_{3}$ was observed at $518 \mathrm{~nm}$ without exciplex emission. Figure 3 presents voltage versus current and luminance versus current characteristics. The device exhibited EL performance with turn-on voltage of 7.5 $\mathrm{V}$ and maximum luminance of $15200 \mathrm{~cd} / \mathrm{m}^{2}$ at $7 \mathrm{~mA}$. The current density dependency of power and luminance efficiency is depicted in Figure 4. The maximum luminance efficiency was $23.6 \mathrm{~cd} / \mathrm{A}$ at $4.4 \mathrm{~mA} / \mathrm{cm}^{2}$. The EL study

Table 1. Summary of UV-Vis and PL spectra of $\mathbf{1}$ and $\mathbf{2}$ in $\mathrm{CHCl}_{3}$ solution

\begin{tabular}{cccccc}
\hline Compound & $\begin{array}{c}\lambda_{\mathrm{abs}} / \mathrm{nm} \\
\left(\varepsilon / \mathrm{L}^{-1} \mathrm{~cm}^{-1}\right)\end{array}$ & $\begin{array}{c}E_{\mathrm{g}} / \mathrm{eV} \\
(\mathrm{UV} / \mathrm{nm})^{a}\end{array}$ & $\lambda_{\mathrm{em}} / \mathrm{nm}$ & $\begin{array}{c}\mathrm{FWHM} \\
/ \mathrm{nm}^{b}\end{array}$ & $\eta_{\mathrm{PL}}{ }^{c}$ \\
\hline $\mathbf{1}$ & $316(15100), 323(15300)$ & $3.54(350)$ & 356 & 54 & 0.007 \\
\hline
\end{tabular}

${ }^{a}$ Optical bandgap was determined from the absorption edge (value in parentheses) of the UV-Vis spectra. ${ }^{b}$ Full-width at half-maximum (FWHM) of PL spectra. ${ }^{c} \mathrm{PL}$ quantum efficiency was determined by using quinine sulfate dihydrate in $1 \mathrm{~N} \mathrm{H}_{2} \mathrm{SO}_{4}$ solution $(\eta=0.55)$ as a standard. ${ }^{10}$ 
Table 2. Electrochemical data ( $v s$. SCE) and energy levels of $\mathbf{1}$ and $\mathbf{2}$ in acetonitrile solution

\begin{tabular}{|c|c|c|c|c|c|c|c|c|c|}
\hline \multirow{2}{*}{ Compound } & \multicolumn{3}{|c|}{$p$-doping ${ }^{a} / \mathrm{V}$} & \multicolumn{3}{|c|}{$n$-doping ${ }^{a} / \mathrm{V}$} & \multirow{2}{*}{$\begin{array}{c}\mathrm{HOMO}^{b} \\
/ \mathrm{eV}\end{array}$} & \multirow{2}{*}{$\begin{array}{c}\mathrm{LUMO}^{b} \\
/ \mathrm{eV}\end{array}$} & \multirow{2}{*}{$\begin{array}{c}\mathrm{E}_{\mathrm{g}} / \mathrm{eV} \\
\text { (EChem) }\end{array}$} \\
\hline & $E_{\text {onset }}$ & $E_{\mathrm{pa}}$ & & & $E_{\mathrm{pc}}$ & $E_{\mathrm{pa}}$ & & & \\
\hline 1 & 2.32 & - & -3.41 & -6.72 & -1.60 & -0.39 & -6.72 & -3.41 & 3.31 \\
\hline 2 & 1.98 & - & -3.53 & -6.38 & -1.30 & -0.50 & -6.38 & -3.53 & 2.85 \\
\hline
\end{tabular}

${ }^{a} E_{\mathrm{onset}}, E_{\mathrm{pa}}$ and $E_{\mathrm{pc}}$ Stand for onset potential, anodic peak potential and cathodic peak potential, respectively. ${ }^{b}$ The energy levels were calculated using the empirical equation: $E=-\left(E_{\text {onset }}+4.4\right) .^{12}$

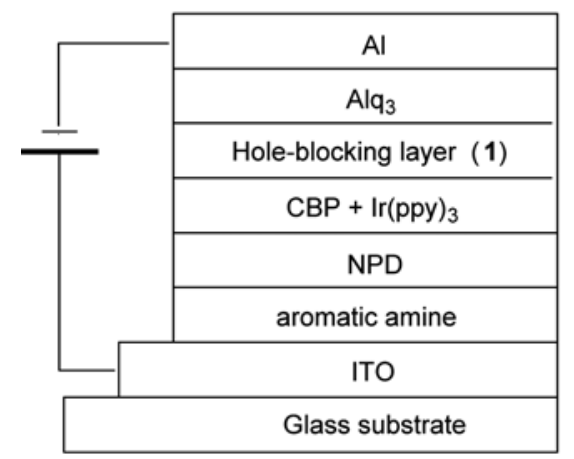<smiles></smiles>

$\operatorname{Ir}(\mathrm{ppy})_{3}$<smiles>c1ccc2c(c1)c1ccccc1n2-c1ccc(-c2ccc(-n3c4ccccc4c4ccccc43)cc2)cc1</smiles>

CBP

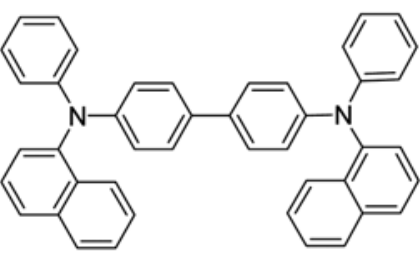

NPD

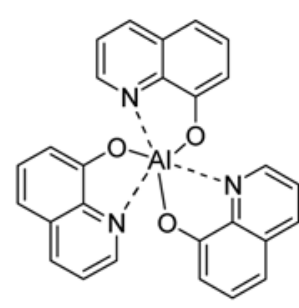

$\mathrm{Alq}_{3}$

Figure 2. Structures of PhOLED and the used materials.

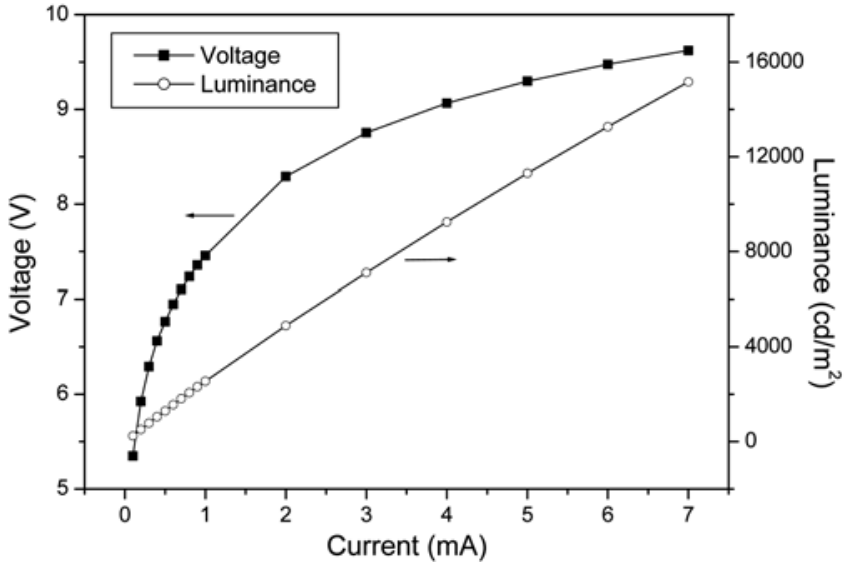

Figure 3. V-I-L characteristics of 1-based PhOLED.

shows that the new compound, 1 functions as a good holeblocking material for the green phosphorescent OLED.

\section{Conclusion}

The synthesis and various properties of two 5,6-dihydro$[1,10]$ phenanthroline derivatives, $\mathbf{1}$ and $\mathbf{2}$ are reported in this paper. The introduction of electron-donating methoxy group in 2 causes broadening of the emission spectrum and lowering of thermal and electrochemical stability compared to $\mathbf{1}$. The green phosphorescent organic light-emitting diode

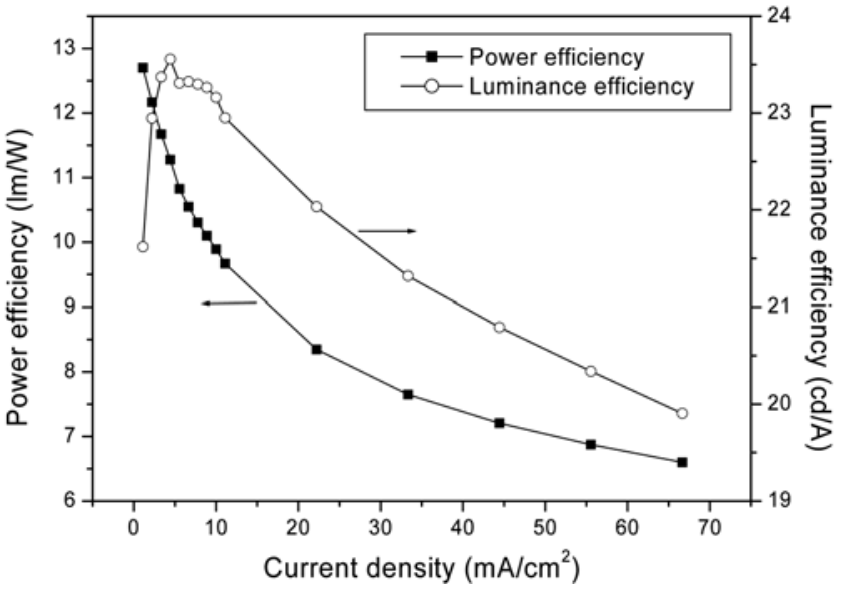

Figure 4. Device efficiency of 1-based PhOLED.

with 1 as a hole-blocking layer showed good luminance efficiency.

Acknowledgement. This research was supported by CMDS, KOSEF and MOCIE. In particular, HWL appreciates the financial support from Nuri research project.

\section{References}

1. (a) Mitschke, U.; Bäuerle, P. J. Mater. Chem. 2000, 10, 1471. (b) Sibley, S.; Thompson, M. E.; Burrows, P. E.; Forrest, S. R. In 
Optoelectronic Properties of Inorganic Compounds; Roundhill, D. M.; Fackler, J. P. Jr., Eds.; Plenum Press: New York, 1999; pp 29-54. (c) You, B.; Kim, H. J.; Park, N. G.; Kim. Y. S. Bull. Korean Chem. Soc. 2001, 22, 1005. (d) Kim, J. H.; Lee, H. Bull. Korean Chem. Soc. 2004, 25, 652. (e) Cheon, J.-W.; Lee, C.-W.; Geum, N.; Gong, M.-S. Bull. Korean Chem. Soc. 2004, 25, 1202. (f) Kang, J.-G.; Kim, T.-J.; Park, C.; Woo, L. S.; Kim, J. T. Bull. Korean Chem. Soc. 2004, 25, 704.

2. Baldo, M. A.; O’Brien, D. F.; You, Y.; Shoustikov, A.; Sibley, S.; Thompson, M. E.; Forrest, S. R. Nature 1998, 395, 151.

3. Baldo, M. A.; O’Brien, D. F.; Thompson, M. E.; Forrest, S. R. Phys. Rev. B 1999, 60, 14422 .

4. Adamovich, V. I.; Cordero, S. R.; Djurovich, P. I.; Tamayo, A.; Thompson, M. E.; D'Andrade, B. W.; Forrest, S. R. Org. Elec. 2003, 4, 77.

5. (a) Baldo, M. A.; Lamansky, S.; Burrows, P. E.; Thompson, M. E.; Forrest, S. R. Appl. Phys. Lett. 1999, 75, 4. (b) Ika, M.; Tokito, S.; Sakamoto, Y.; Suzuki, T.; Taga, Y. Appl. Phys. Lett. 2001, 79, 156.

6. (a) Wang, Y.; Herron, N.; Grushin, V. V.; LeCloux, D.; Petrov, V. Appl. Phys. Lett. 2001, 79, 449. (b) Ono, K.; Yanase, T.; Ohkita,
M.; Saito, K.; Matsushita, Y.; Naka, S.; Okada, H.; Onnagawa, H Chem. Lett. 2004, 33, 276.

7. (a) Kinoshita, M.; Kita, H.; Shirota, Y. Adv. Func. Mater. 2002, 12 , 780. (b) Okumoto, K.; Shirota, Y. Chem. Mater. 2003, 15, 699.

8. Adachi, C.; Kwong, R. C.; Djurovich, P.; Adamovich, V.; Baldo, M. A.; Thompson, M. E.; Forrest, S. R. Appl. Phys. Lett. 2001, 79 , 2082.

9. Thummel, R. P.; Lefolulon, F.; Cantu, D.; Mahadevan, R. J. Org. Chem. 1984, 49, 2208.

10. (a) Demas, J. N.; Crosby, G. A. J. Phys. Chem. 1971, 75, 991. (b) Joshi, H. S.; Jamshidi, R.; Tor, Y. Angew. Chem. Int. Ed. 1999, 38, 2722.

11. Ko, S. W.; Jung, B.-J.; Cho, N. S.; Shim, H.-K. Bull. Korean Chem. Soc. 2002, 23, 1235 .

12. (a) Chen, Z.-K.; Huang, W.; Wang, L.-H.; Kang, E.-T.; Chen, B. J.; Lee, C. S.; Lee, S. T. Macromolecules 2000, 33, 9015. (b) de Leeuw, D. M.; Simenon, M. M. J.; Brown, A. R.; Einerhand, R. E. F. Synth. Met. 1997, 87, 53. (c) Brédas, J. L.; Sibley, R.; Boudreaux, D. S.; Chance, R. R. J. Am. Chem. Soc. 1983, 105, 6555. 